\section{STUDIES ON THE FACTOR, RESPONSIBLE FOR INCREASED TRIGLYGERIDE SYNTHESIS IN TETRACYCLINE-TREATED RAT}

\author{
Debesh Mukherjee and \\ Suprovat Mukherjee \\ Department of Applied Chemistry, \\ University of Calcutta, India
}

(Received for publication May 29, 1969)

Liver is the major source of plasma triglyceride $^{1)}$. A number of pharmacologically active compounds such as carbon tetrachloride $^{2)}$, ethanol ${ }^{3)}$ and tetracycline ${ }^{4)}$ have been reported to increase the lipid content of the liver. Horning et al. ${ }^{5)}$ demonstrated in homogenates that the fatty-liver induced by administration of ethanol, mainly due to stimulation of triglyceride synthesis and incorporation of $1-{ }^{14} \mathrm{C}$-palmitate into triglyceride with lower incorporation into phospholipid, can be reversed by addition of CDP-choline to the medium. We demonstrated $^{6)}$ that secretion of triglyceride by the liver is impaired after administration of tetracycline to rats and the stimulating effect of tetracycline on triglyceride synthesis in liver homogenate of drug-treated animal is not observed if the antibiotic is administered to adrenalectomised animals.

Since phospholipid synthesis is influenced by limited availability of co-factors ${ }^{7)}$ and since the free fatty acids are the precursor of both phospholipid and triglyceride of the liver, the present study describes the result of administration of tetracycline on the relative distribution of injected $1{ }^{14} \mathrm{C}$-palmitate into triglyceride and phospholipid fraction of the rat liver and the effect of addition of different co-factors of phospholipid synthesis in liver homogenate preparation of drug-treated rats.

\section{Materials and Methods}

Tetracycline hydrochloride was obtained from Standard Pharmaceutical Ltd., Calcutta. Adenosine triphosphate (ATP), cyti- dine triphosphate (CTP) and cytidine diphosphate choline (CDP-choline) was purchased from Sigma Chemical Co., U.S.A., Silica gel $G$ was obtained from E. Merck, $\mathrm{W}$. Germany and $1{ }^{14} \mathrm{C}$-palmitate was obtained from Radio-Chemical Centre, Amersham, England.

Male albino rats weighing $100 \sim 120 \mathrm{~g}$ were kept on stock ration. Tetracycline hydrochloride in aqueous solution was administered intramuscularly for a period of 7 days to a group of rats at a dose level of $3.5 \mathrm{mg}$ per $100 \mathrm{~g}$ of body-weight of the animals. The animals were sacrificed 3 hours after the last dose of drug. The liver was quickly removed and homogenized in Tris- $\mathrm{KCl}$ buffer ( $\mathrm{pH}$ 7.4) and immediately incubated in a fully fortified medium ${ }^{8)}$ at $37^{\circ} \mathrm{C}$ for 30 minutes in a Dubnoff shaker. The reaction was stopped by addition of $0.5 \mathrm{ml}$ of $10 \%$ TCA. Total lipid content of the incubation medium containing liver homogenate was extracted three times with $25 \mathrm{ml}$ of chloroform-methanol mixture. The solvent containing the lipid was evaporated and last trace of solvent was removed under vacuum.

Relative distribution of $1{ }^{14} \mathrm{C}$-palmitate into triglyceride and phospholipid content of the liver and serum of drug-treated animals was studied after injection of albumin complex of ${ }^{1-14} \mathrm{C}$-palmitate through the tail vein, 3 hours after the administration of drug. The animals were sacrificed one hour after palmitate administration. Total lipid of the liver was extracted by using the method of Gershbein ${ }^{9)}$ while the serum lipid was extracted following the procedure of SPERRY and BRAND ${ }^{10)}$. Separation of triglyceride ${ }^{11)}$ and phospholipid ${ }^{12)}$ for assay of radio-activity was carried out using thin-layer chromatography and all assessment of radio-activity was carried out with the Tracerlab Model SA-SC ISA Superscalar gas flow counter. Self absorption correction was made in all cases.

\section{Results and Discussion}

The incorporation of intravenously administered $1{ }^{14} \mathrm{C}$-palmitate in the phospholi- 
Table 1. Comparative utilization of intravenously administered radio-palmitate for triglyceride and phospholipid synthesis in control and tetracycline-treated rats.

\begin{tabular}{c|lc|r|r|c}
\hline \multirow{2}{*}{} & & \multicolumn{2}{|c|}{$\begin{array}{c}1-{ }^{14} \mathrm{C}-\text { Palmitate activity in cpm } \\
\text { (per g or per ml) }\end{array}$} & $\begin{array}{c}\text { Phospholipid/Triglyceride } \\
\text { Ratio }\end{array}$ \\
\cline { 3 - 5 } & & Triglyceride & Phospholipid & 1.38 \\
\hline \multirow{2}{*}{$\begin{array}{c}\text { Liver } \\
\text { tissue }\end{array}$} & Control & Tetracycline-treated (6) & $21,000 \pm 300$ & $5,230 \pm 105$ & 0.24 \\
\hline \multirow{2}{*}{ Serum } & Control & $(6)$ & $2,000 \pm 75$ & $1,150 \pm 100$ & 0.57 \\
& Tetracycline-treated (6) & $1,150 \pm 120$ & $650 \pm 80$ & 0.56 \\
\hline
\end{tabular}

$1{ }^{14} \mathrm{C}$-Palmitate $\left(8.5 \times 10^{5} \mathrm{cpm} / 100 \mathrm{~g}\right.$ of body weight) was administered as albumin complex to each rat through the tail vein 3 hours after administration of $3.5 \mathrm{mg}$ tetracycline per $100 \mathrm{~g}$ of body weight of rat. Duplicate aliquots of lipid extract were used for thin-layer chromatographic separation. Blood was drawn by cardiac puncture at the end of 1 hour after $1-{ }^{14} \mathrm{C}$-palmitate administration and liver excised after killing the animal immediately after the collection of blood.

Figure in parenthesis represents the number of animals.

pid and triglyceride fraction of the liver and serum of tetracycline-treated and control rats is presented in Table 1. The increased radio-activity in triglyceride fraction of liver, and simultaneous decrease in serum triglyceride of drug-treated animals, indicate that the release of newly synthesised triglyceride from liver to the circulation is impaired, is in accord with our previous observation. Following administration of $1-{ }^{14} \mathrm{C}$-palmitate, increased radio-activity appears in the phospholipid fraction of the liver of control group in comparison with the drug-treated animals. The palmitate radio-activity in the serum phospholipid moiety of control animals is also much higher than that of tetracycline-treated rats. The data clearly indicate that phospholipid: triglyceride radio-activity ratio of serum of both control and tetracycline-treated groups are almost identical inspite of the decrease in activity of phospholipid and triglyceride moieties of the serum of drugtreated group. The decrease in phospholipid: triglyceride radio-activity ratio in liver of drug-treated rats is due to less incorporation of palmitate activity in phospholipid and increased incorporation of $1-{ }^{14} \mathrm{C}$-palmitate into triglyceride, which is mainly retained in the liver as a result of impaired secretion into the circulation. Since there is less incorporation of labelled palmitate into phospholipid of both liver and serum of drug-treated animals and incorporation of $1-{ }^{14} \mathrm{C}$-palmitate into liver glyceride is maximum, preferential utilization of free fatty acid for triglyceride synthesis in liver of drug-treated animal, is indicated.

The effect of supplementation of CTP and $\mathrm{CDP}$-choline on incorporation of $1{ }^{14} \mathrm{C}$ palmitate into phospholipids and triglycerides in liver homogenate of control and tetracycline-treated rats using in vitro incubation system, is summarized in Table 2. In these experiments increased radio-activity in triglyceride and a decreased incorporation of ${ }^{1-{ }^{14} \mathrm{C}}$-palmitate in phospholipid was observed under the conditions of the test. The experimental conditions outlined by Stein et al. ${ }^{8)}$ are optimal for triglyceride synthesis and the lower incorporation of radio-activity in liver phospholipid in these in vitro experiments may not represent the true rates of synthesis in the intact animals. However, in the control group, supplementation of either CTP or CDP-choline in the medium does not appreciably alter the distribution of palmitate radio-activity between two lipid categories. When CTP is added to liver homogenate of tetracycline-treated rats, a stimulation of phospholipid synthesis is observed but the rate of synthesis is still lower than in the control group. When the incubation mixture is fortified with 2 micromoles of CDP-choline, significant fall in triglyceride synthesis is obtained, concomitant with increased incorporation of palmitate radio-activity in the phospholipid fraction and the hepatic rate of phospholipid bio-synthesis approaches almost double the observed value in tetracycline-treated rat liver homogenate without any supplement 
Table 2. Effect of in vitro addition of CTP and CDP-choline on synthesis of triglycerides and phospholipids in liver homogenates of control and tetracycline-treated rats.

\begin{tabular}{|c|c|c|c|c|}
\hline \multirow{2}{*}{$\begin{array}{c}\text { Liver } \\
\text { homogenate }\end{array}$} & \multirow{2}{*}{$\begin{array}{l}\text { Addition to } \\
\text { standard } \\
\text { incubation } \\
\text { medium* for } \\
\text { triglyceride } \\
\text { synthesis }\end{array}$} & \multicolumn{2}{|c|}{ Incorporation of ${ }^{1-14} \mathrm{C}$-palmitate radio-activity } & \multirow{2}{*}{$\begin{array}{c}\text { Phospholipid/ } \\
\text { Triglyceride } \\
\text { Ratio }\end{array}$} \\
\hline & & $\begin{array}{l}\text { Triglyceride }(\mathrm{cpm} / \mathrm{mg} \\
\text { of liver protein) }\end{array}$ & $\begin{array}{c}\text { Phospholipids ( } \mathrm{cpm} / \mathrm{mg} \\
\text { of liver protein) }\end{array}$ & \\
\hline Control & $\begin{array}{c}\text { None } \\
\text { CTP }(2 \mu \mathrm{m}) \\
\text { CDP-Choline } \\
(2 \mu \mathrm{M})\end{array}$ & $\begin{array}{l}3,532 \pm 235 \\
3,576 \pm 200 \\
3,580 \pm 195\end{array}$ & $\begin{array}{l}875 \pm 80 \\
970 \pm 60 \\
960 \pm 81\end{array}$ & $\begin{array}{l}0.25 \\
0.27 \\
0.26\end{array}$ \\
\hline $\begin{array}{c}\text { Tetracycline- } \\
\text { treated } \\
(3.5 \mathrm{mg} / 100 \mathrm{~g})\end{array}$ & $\begin{array}{c}\text { None } \\
\text { CTP }(2 \mu \mathrm{m}) \\
\text { CDP-Choline } \\
(2 \mu \mathrm{M})\end{array}$ & $\begin{array}{l}6,400 \pm 216 \\
4,515 \pm 270 \\
3,475 \pm 250\end{array}$ & $\begin{array}{r}590 \pm 25 \\
755 \pm 50 \\
1,100 \pm 50\end{array}$ & $\begin{array}{l}0.092 \\
0.167 \\
0.32\end{array}$ \\
\hline
\end{tabular}

* Standard incubation mixture contained: $10 \mu$ moles, $\mathrm{K}$ - $\alpha$-glycerophosphate, $10 \mu$ moles ATP, 10 $\mu$ moles $\mathrm{MgCl}_{2}, 2.5 \mu$ moles $\beta$-mercaptoethanol, $20 \mu$ moles $\mathrm{K}$-phosphate-buffer $0.5 \mathrm{ml}$ liver homogenate, $0.1 \mu$ moles of ${ }^{1-14} \mathrm{C}$-palmitate $(85,000 \mathrm{cpm})$, and made upto $2.5 \mathrm{ml}$ with $\mathrm{KCl}$-Tris buffer $(\mathrm{pH} 7)$.

Figures in parenthesis represent number of animals.

of co-factors of phospholipid synthesis. In fact, the phospholipid specific activity approaches the value observed in control animals under similar conditions. Since the pattern of incorporation of $1{ }^{14} \mathrm{C}$-palmitate into phospholipids by liver homogenate of tetracycline administered rats returns to normal by addition of CDP choline, it is possible that this co-factor is limited in liver of tetracycline-treated animals. In absence of optimal amounts of this essential co-factor, free fatty acids are preferentially converted to triglycerides in the liver of drug-treated rats. The possibility exists that there is either block in the enzymatic synthesis of CDP-choline after tetracycline treatment or inadequacy of this co-factor may be due to increased requirement of the co-factor for phospholipid synthesis in tetracycline-treated animals.

\section{Summary}

In the intact tetracycline-treated rat, incorporation of injected $1{ }^{14} \mathrm{C}$-palmitate into liver triglyceride increases while it is decreased in phospholipid fraction. There is no increased incorporation of $1{ }^{14} \mathrm{C}$-palmitate in triglyceride fraction of liver homogenate of tetracycline-treated rats after addition of CDP-choline to the medium. These indicate that in absence of optimal amount of this co-factor of phospholipid synthesis, free fatty acids are preferentially converted to triglycerides in the liver of antibiotic treated rats.

\section{References}

1) Byers, S. O. \& M. Friedman: Site of origin of plasma triglyceride. Am. J. Physiol. 198: $629 \sim 631,1960$

2) Horning, M. G.; M. WaKabayashi \& H. M. MALING: Effects of drugs on synthesis and mobilisation of lipids. Horning, E. C. ed. Pergamon Press, U.S.A. 1963.

3) Scheig, R. \& K. J. Isselbacher: Pathogenesis of ethanol-induced fatty liver. III. In vivo and in vitro effects of ethanol on hepatic fatty acid metabolism in rats. J. Lipid Research 6 : 269 277, 1965

4) Moser, H. R: Reactions to tetracyclines. Clin. Pharma. \& Therap. $7: 117 \sim 132,1966$

5) Horning, M. G.; M. WaKabayashi \& H. M. MALING: Biochemical processes involved in the synthesis, accumulation and release of triglycerides by liver. First International Pharmacology Meeting, Vol. II, Pargamon Press, 1961.

6) Mukherjee, D. \& S. Mukherjee: Studies on the effects of tetracycline on triglyceride synthesis in experimental rats. J. Antibiotics $22: 45 \sim 48,1969$

7) Kennedy, E. P.: Biosynthesis of complex lipids. Fed. Proc. $20: 934 \sim 940,1961$

8) Stein, Y. \& B. Shapiro: The synthesis of neutral glycerides by fractions of rat liver homogenate. Biochem. Biophy. icta 24 : 197 206, 1957

9) Gershbein, L. L. : Antibiotics and liver regeneration in rats. J. Antibiotics, Ser. A $20: 25 \sim 29,1967$

10) Sperry, W. M. \& F. C. Brand: The determination of total lipids in blood serum. J. Biol. Chem. $213: 69 \sim 72,1955$

11) Levin, E. \& C. Head: Quantitaive analysis of tissue neutral lipids by thin-layer chromatography. Anal. Biochem. $10: 23 \sim 31,1965$

12) Skipski, V.P., R.F. Peterson \& M. Barclay: Quantitative analysis of phospholipids by thin-layer chromatography. Biochem. J. $90: 374 \sim 378,1964$ 